\title{
Performance of Component Species in Three Apple-Berry Polyculture Systems
}

\author{
Tina M. Rivera ${ }^{1}$ and Martin F. Quigley \\ Department of Horticulture and Crop Science, The Ohio State University, \\ Columbus, OH 43210
}

\author{
Joseph C. Scheerens ${ }^{2}$ \\ Department of Horticulture and Crop Science, The Ohio State University, Ohio \\ Agricultural Research and Development Center, Wooster, $\mathrm{OH} 44691$
}

Additional index words. edible landscaping, intercropping, interspecific competition, blackberry, Rubus spp., jostaberry, Ribes nidigrolaria, edible honeysuckle, Lonicera caerulea

\begin{abstract}
The commercial and ornamental potential of three apple-berry polyculture systems was ascertained by monitoring the above-ground performance of component species in plots of 'GoldRush' apple (Malus $\times$ domestica Borkh.) trees on M.7 rootstock cropped with either blackberry (Rubus spp. L. 'Navaho'), edible honeysuckle (Lonicera caerulea L. 'Blue Belle' and 'Blue Velvet'), or jostaberry (Ribes nidigrolaria Bauer 'Josta') as understory plants. Polyculture plots and corresponding monoculture controls were established in 1999, with berry plants at recommended $(\mathbf{R})$ or close $[(\mathbf{C})$, half-recommended] spacings. Blackberries and jostaberries planted in monoculture at recommended spacings [i.e., control $(R)$ plots] amassed dry weights $>1 \mathrm{~kg} /$ plant by Fall 2001 ; the dry weight of edible honeysuckle from comparable plots was slightly $>0.3 \mathrm{~kg} /$ plant. In 2001 , blackberry yield $(3.1 \mathrm{~kg} /$ plant $)$ and fruit weight ( $3.4 \mathrm{~g})$ were typical of 'Navaho' plantings of similar age, whereas jostaberry was only moderately productive (yield $=286 \mathrm{~g} /$ plant; fruit weight $=1.4 \mathrm{~g}$ ). Edible honeysuckle productivity (yield $=13 \mathrm{~g} /$ plant, fruit weight $=0.5 \mathrm{~g}$ ) was minimal, due to disparate flowering phenology between cultivars. 'GoldRush' apple growth and productivity (yield $=\mathbf{2 5} \mathbf{~ k g} /$ tree; fruit weight $=\mathbf{1 5 8} \mathbf{~ g}$ ) was consistent with values expected for trees of similar age. Blackberry plant dry weights were reduced by $20 \%$ to $33 \%$ when planted at close spacing, whereas blackberry yields were reduced $35 \%$ to $38 \%$ when grown in polyculture with apple. Both polyculture and plant spacing significantly reduced jostaberry dry weights (i.e., $12 \%$ and $24 \%$, respectively) relative to the control, but neither significantly affected jostaberry yield. Conversely, both close-spaced planting and the presence of an apple tree improved the yield of edible honeysuckle. Apple performance was not affected by the presence of an edible honeysuckle understory, but apple growth factors were reduced in blackberry and jostaberry polycultures by as much as $65 \%$. Apple bloom, fruit set, and yield were also significantly reduced in apple-blackberry and apple-jostaberry plots, with fruit numbers/tree averaging $<5$ in all except the apple-blackberry $(C)$ treatment. None of the polyculture treatments studied were suitable for profitable fruit production. However, each of the polyculture constituents exhibited unique, beneficial attributes with respect to their use as components within an edible landscape.
\end{abstract}

Polyculture is a traditional farming strategy that promotes diet diversity, minimizes production risks and the incidence of disease and insect infestations, intensifies production with limited human and material resources, and maximizes

Received for publication 13 Nov. 2003. Accepted for publication 18 Feb. 2004. Salaries and research support provided in part by State and Federal funds appropriated to the Ohio Agricultural Research and Development Center, The Ohio State University. Manuscript HCS 03. Manuscript is based on research reported in a dissertation written by Tina M. Rivera in partial fulfillment of her Ph.D. requirements. We thank David C. Ferree for his scholarly advise throughout all phases of this study. We also thankEric Chanay, John Elliott, Diana Hardy, Nathan Krohn, Stacie Reid, John Schmid, David Scurlock, Shawn Shay, and Bruce Williams for technical assistance and the OARDC Minority Associateship Program for additional financial support.

${ }^{1}$ Former graduate student. Current address: $1022 \mathrm{~N}$ Clinton St., Olathe, KS 66061.

${ }^{2}$ To whom reprint requests should be addressed; e-mail scheerens.1@osu.edu. profitable returns under low levels of technology (Altieri, 1987). Commercial food crop polyculture is practiced very infrequently in developed countries of temperate regions, except perhaps for the interplanting grains, vegetables, and small fruits in the alleys during the nonbearing years of orchard establishment. Alley-cropping, common a half century ago, is still profitable today under some circumstances, even though precocious varieties, dwarfing rootstocks, and high-density planting systems have limited available space and shortened establishment periods (Leuty, 1999). Intercropping systems may also offer potential advantages when used in alternative production schemes (e.g., organic production of fruits and vegetables) requiring maximized productivity per unit land area or when product diversity is highly desired (e.g., niche marketing strategies).

Fueled with increased interest in the perceived health benefits of home-grown produce, the polyculture of fruit and vegetable crops is becoming more commonplace in kitchen gardens or diversified landscapes in many urban or suburban communities (Creasy, 1982; Hagy, 1990). Polycultures of edible plants or of edible and ornamental plants also represent an ecological or sustainable approach to landscaping beyond that of ornamental culture alone (Beck et al., 2002; Beck and Quigley, 2002). Specifically, combinations of fruit-bearing plants, such as fruit trees planted with an understory of fruit-bearing bushes or groundcover, may provide aesthetic and economic benefits to home-owners, yielding both flowers and fruit. Because component species would be planted in closer proximity in the ornamental landscape than they might for commercial fruit production, weed growth may also be curtailed. However, competitive interactions between component crops can significantly affect crop performance of both tree and understory species (Corlett et al., 1992a, 1992b; Farrell, 1987; Leuty, 1999). Competition may be especially relevant if the components of these polyculture systems are planted at spacings designed for an aestheticallypleasing landscape during tree establishment.

Our overall research goal was to compare three potential tree-based, intercropping systems in which component species are woody perennials that produce a valued fruit crop: 'GoldRush' apple on M.7 rootstock intercropped with ' $\mathrm{Na}$ vaho' blackberry, 'Blue Belle' and 'Blue Velvet' edible honeysuckle or 'Josta' jostaberry. In this paper, we report the above-ground performance of component species within systems based upon growth, flowering, fruit set, and fruit yield. Systems were evaluated for their cropping potential based in part, on calculation of their land equivalent ratios (LER), and for their suitability in the residential landscape according to their individual habit, flower and foliage characteristics, and ability to thrive in close proximity with other woody plants.

\section{Materials and Methods}

An apple-berry polyculture experiment was planted in May and June 1999 at the Ohio Agricultural Research and Development Center (OARDC) in Wooster, Ohio. The soil type was a Wooster silt loam (fine-loamy, mixed mesic Typic Fragiudalf). Plant materials were purchased from commercial nurseries. Bare-root stock of 'GoldRush'/M.7 apple and 'Navaho' blackberries were obtained, whereas 'Josta' jostaberries and 'Blue Belle' and 'Blue Velvet' honeyberries were acquired as container plants. Apples were planted on 20 May and the berries were planted on 18,21, and 23 June 1999. Berry plant volumes were estimated on 21 July 1999 by measuring the height of the longest shoot and spread in two directions to ascertain that plants assigned to the various treatments were of nearly equal size at the beginning of the experiment (data not shown).

Experimentaldesign and culture. The experiment consisted of 13 treatments; each treatment was replicated five times in a randomized complete block design. Experimental plots were 3 $\times 3 \mathrm{~m}$ with within row plot centers $5 \mathrm{~m}$ apart. Rows were oriented south to north. Six of the treatments were apple-berry polycultures (apple + one of three berry species $\times$ two spacings). An apple tree was planted at the center of each poly- 
culture plot. Four understory plants of a single berry species were positioned equidistantly from the apple at the northeast, southeast, northwest and southwest corners of each plot. Berries were planted at $1.2 \mathrm{~m}$ within rows $(\mathrm{S}-\mathrm{N})$ and at either recommended between-row spacings or close (one-half recommended) between-row spacings (i.e., either $0.9 \mathrm{~m}$ or $1.8 \mathrm{~m}$ apart for edible honeysuckle and jostaberries and either 1.2 or $2.4 \mathrm{~m}$ apart for blackberries). The remaining seven treatments were monocultures of apple or of berry understory crops planted at close (C) or recommended $(\mathrm{R})$ spacings serving as controls for the polyculture treatments, respectively. Edible honeysuckle plots contained one row (two plants) of each cultivar to ensure needed cross-pollination.

Planting holes were amended with (by volume) of 1 peat: 1 native soil. Plots were covered with landscape fabric for weed control; weeds emerging from plant crowns were controlled by hand. Pesticides were sprayed as needed. On 3 May 2000, a 3-cm-deep layer of wood chip mulch was placed around the base of each plant to further suppress weeds. A fresh layer of mulch was applied in April 2001. Immediately after planting, apple scions were topped at $1 \mathrm{~m}$ and thereafter, were not pruned except to remove damaged branches. Trees were trained as central leaders and crotch angles of scaffold branches
(30 $\mathrm{cm}$ in length) were improved by bending manually to a more horizontal position using clothespins. Blackberries were summer-tipped to promote lateral branching and winter-pruned to trim laterals to 30 to $40 \mathrm{~cm}$ and to remove damaged primocanes and spent floricanes as recommended by Funt et al. (2001). Pruned blackberry tissue was dried in a plant tissue dryer and then weighed. Jostaberry and edible honeysuckle plants were not pruned.

Data collection. Berry plant performance was determined, in part, by measuring aboveground growth. In order quantify this parameter nondestructively in field plots, 23 plants of each berry species were greenhouse-cultured for 12 months in 13.6-L pots. In June and July 2000, these plants were harvested, sectioned and dried to determine the growth variables that provided the best estimate of above-ground dry weight. Consequently, blackberry growth was estimated by measuring the total number of canes, the total number of laterals, and the length of the first and third longest shoots $\left(P<0.0001, r^{2}\right.$ $=0.72$ ). In addition, pruned blackberry canes taken during the year were separated by age of the wood, bagged, dried, and weighed and their dry weight was included cumulatively in growth estimates. Jostaberry growth was estimated by measuring the diameter of the largest scaffold branch at $5 \mathrm{~cm}$ above the ground, the length of first and second longest shoots, the total number of scaffolds, the total number of laterals, and the width and height of the plant $\left(P<0.03, r^{2}\right.$ $=0.55)$. The two edible honeysuckle cultivars had to be measured using different variables due to the difference in their growth habits. 'Blue Velvet' growth was estimated by measuring the total number of scaffolds, the total number of laterals, and the length of the longest shoot $\left(P<0.001, r^{2}=0.91\right)$. 'Blue Belle' growth was estimated by measuring the diameter of the largest scaffold at $4 \mathrm{~cm}$ above the ground, the total number of scaffolds, the length of the first and third longest shoots, and the width and height of the plant $\left(P<0.03, r^{2}=0.89\right)$. Subsequent growth measurements for berry species were taken on 11 Oct. 2000 and 20 Oct. 2001.

For each berry species, flowering, percent fruit set, fruit weight and fruit yield were also measured in 2000 and 2001. 'Blue Velvet' edible honeysuckle flowers were counted on $28 \mathrm{Apr}$. 2000 as were floral remnants on 'Blue Belle'. Flowers were also counted on 13 Apr. 2001 for 'Blue Belle' and on 19 Apr. 2001 for 'Blue Velvet'. Fruit were harvested on 25 and 29 May 2001. Jostaberry bloom was measured 28 Apr. 2000 and 24 Apr. 2001; berries were harvested on 30 June and 17 July 2000 and on 28 June and 5, 13, and 19 July 2001. In 2000, blackberry bloom was measured on two canes per plant on
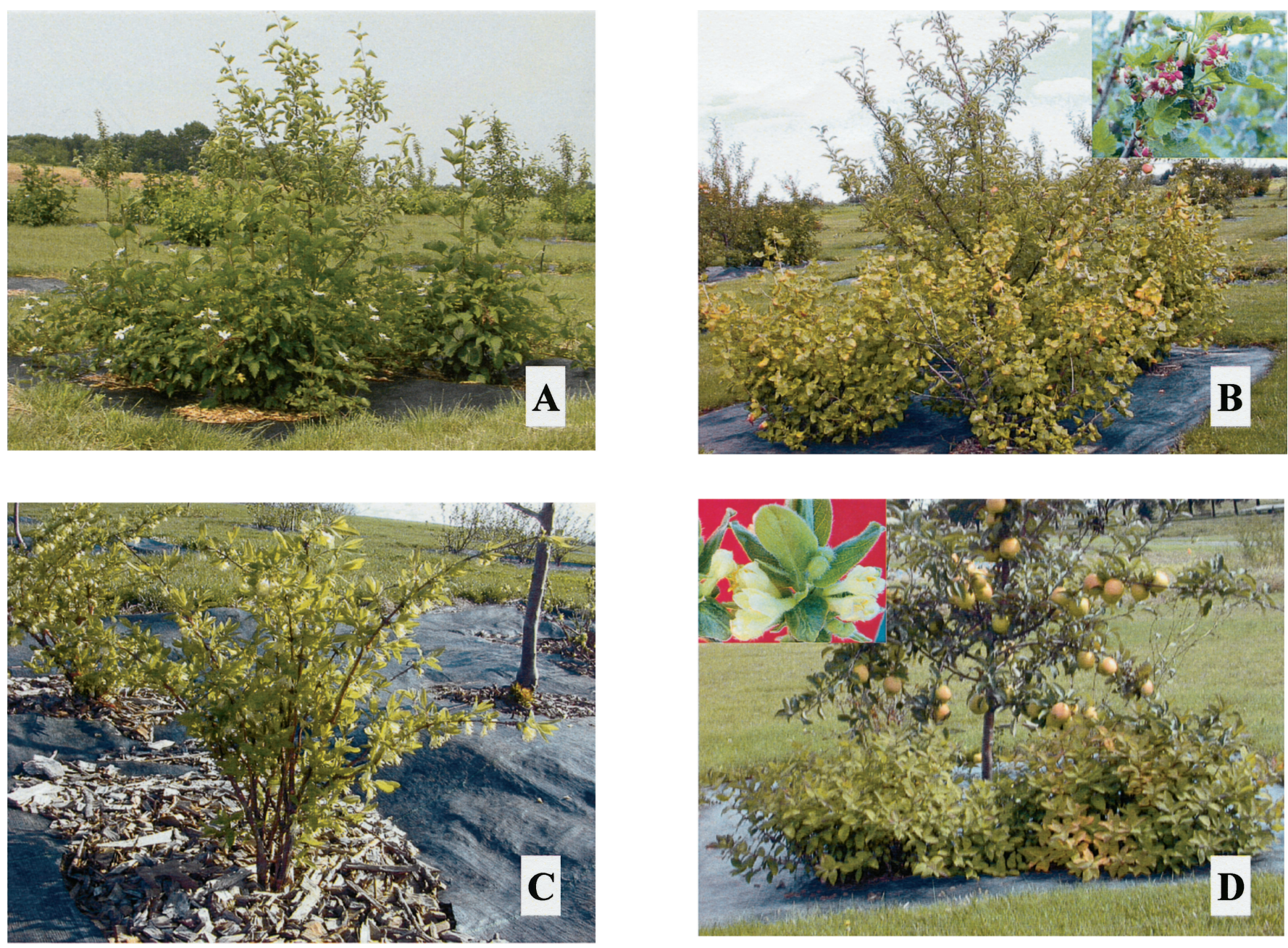

Fig. 1. Shrubs in closely spaced (C) polyculture with apple during their second year of growth: (A) 'Navaho' blackberry, (B) 'Josta' jostaberry, (C) 'Blue Velvet' edible honeysuckle, and (D) 'Blue Belle' edible honeysuckle. Inserts in $\mathbf{B}$ and $\mathbf{D}$ depict flowers of 'Josta' and 'Blue Belle', respectively. 
Table 1. Comparison of understory species and cultivars grown in monoculture at recommended spacings for mean dry weight, number of flowers, percent fruit set, yield, and berry weight.

\begin{tabular}{|c|c|c|c|c|c|c|c|c|c|c|}
\hline \multirow[b]{2}{*}{$\begin{array}{l}\text { Species } \\
\text { or cultivar }\end{array}$} & \multicolumn{5}{|c|}{2000} & \multicolumn{5}{|c|}{2001} \\
\hline & $\begin{array}{l}\text { Dry wt } \\
(\mathrm{g} / \text { plant })^{\mathrm{z}}\end{array}$ & $\begin{array}{c}\text { No. of } \\
\text { flowers }\end{array}$ & $\begin{array}{c}\text { Fruit set } \\
(\%)^{\mathrm{y}}\end{array}$ & $\begin{array}{c}\text { Yield } \\
(\mathrm{g} / \text { plant })^{\mathrm{x}}\end{array}$ & $\begin{array}{l}\text { Fruit wt } \\
\text { (g/fruit) }{ }^{y}\end{array}$ & $\begin{array}{l}\text { Dry wt } \\
\text { (g/plant) }\end{array}$ & $\begin{array}{l}\text { No. of } \\
\text { flowers }\end{array}$ & $\begin{array}{c}\text { Fruit set } \\
(\%)\end{array}$ & $\begin{array}{c}\text { Yield } \\
\text { (g/plant) }\end{array}$ & $\begin{array}{l}\text { Fruit wt } \\
\text { (g/fruit) }\end{array}$ \\
\hline \multicolumn{11}{|c|}{ Differences among understory species } \\
\hline Blackberry & $568 \pm 20^{w}$ & $442 \pm 47$ & $82 \pm 5$ & $1473 \pm 227$ & $4.0 \pm 0.1$ & $1360 \pm 93$ & $1051 \pm 103$ & $96 \pm 5$ & $3116 \pm 249$ & $3.4 \pm 0.2$ \\
\hline Edible honeysuckle & $183 \pm 5$ & $56 \pm 11$ & $\mathrm{ND}^{\mathrm{v}}$ & ND & ND & $312 \pm 9$ & $153 \pm 12$ & $22 \pm 5$ & $13 \pm 3$ & $0.5 \pm 0.01$ \\
\hline Jostaberry & $745 \pm 20$ & $38 \pm 5$ & $35 \pm 4$ & $24 \pm 6$ & $1.7 \pm 0.2$ & $1071 \pm 43$ & $1220 \pm 225$ & $17 \pm 1$ & $286 \pm 49$ & $1.4 \pm 0.03$ \\
\hline \multicolumn{11}{|c|}{ Differences between edible honeysuckle cultivars } \\
\hline Blue Belle & 153 & 36 & ND & ND & ND & 336 & 95 & 36 & 13 & 0.4 \\
\hline Blue Velvet & 211 & 76 & ND & ND & ND & 287 & 210 & 9 & 12 & 0.7 \\
\hline Significance & $* *$ & $*$ & & & & NS & $* *$ & $* *$ & NS & $* * * *$ \\
\hline
\end{tabular}

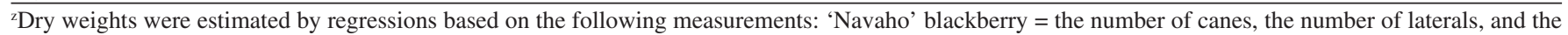

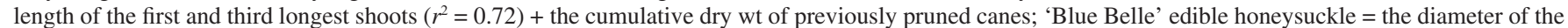

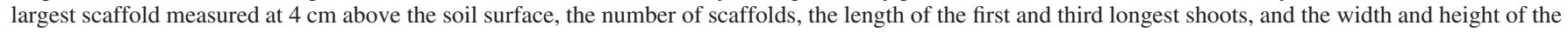

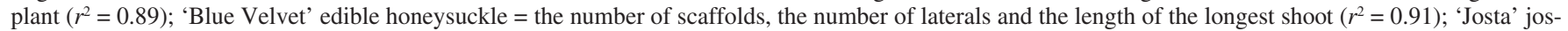

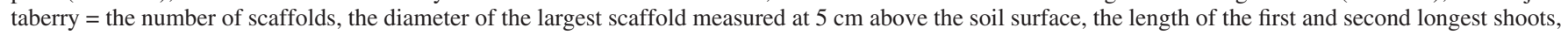
the number of laterals, and the width and height of the plant $\left(r^{2}=0.55\right)$.

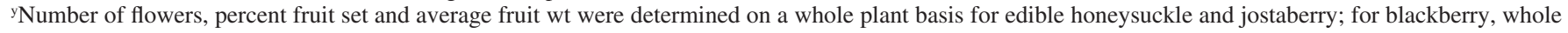
plant values for these parameters were estimated from the performance of two subsamples in each plant.

${ }^{x}$ Yield was recorded on a whole plant basis cumulatively over harvests.

"Values represent mean of individual plants \pm standard error of the mean summed over all replicates of the control plots.

${ }^{\mathrm{N}} \mathrm{ND}=$ not determined; fruit wt could not be calculated due to a lack of harvested fruit.

NS, ${ }^{* * *, * * * *}$ Nonsignificant or significant differences in cultivars at $P=0.05,0.01$, or 0.0001 , respectively as determined by analysis of variance.

2 June and berries were harvested on 17 July; 2, 11, and 24 Aug.; 1, 7, 20, and 27 Sept.; and 3 and 10 Oct. In 2001, blackberry bloom was measured on two canes per plant on 7 June and berries were harvested on 19, 22, and 27 July; 2, 8, 14, 21, 28 Aug.; and 5, 11, 18, and 25 Sept. Blackberry yields were also recorded on a whole plant basis on the same days.

Apple performance was determined by measuring shoot length, trunk cross-sectional area, flowering, percent fruit set, fruit weight and fruit yield. The diameter of the apple trunks at $30 \mathrm{~cm}$ above the graft union was measured on a yearly basis: 1 July 1999, 11 Nov. 1999, 11 Oct. 2000, and 15 Oct. 2001. Diameter measurements were then converted to trunk cross-sectional area. Flower clusters on each tree were counted on 24 Apr. 2000, 24 Apr. 2001, and 10 Apr. 2002. Apples were harvested and weighed on 10 Oct. 2000 and 17 Oct. 2001. For each year, the percentage of fruit set was calculated.

Data analysis and interpretation. Data were analyzed using software and procedures (PROC GLM and/or PROC MEANS) in accordance with the SAS Institute (1990). The general horticultural performance of component species was compared using data from monoculture plots grown at recommended spacings. To assess the effect of polyculture and plant spacing on berry performance, three subsets of the data (i.e., one subset per species) were analyzed as randomized complete blocks in four treatments and five replications. To compare apple performance parameters among treatments, a data subset containing observations from plots containing apple grown in polyculture or monoculture were analyzed as a randomized complete block in seven treatments and five replications.

The advantage or disadvantage of polyculture for fruit production was assessed by comparing the yield potential of component crops in monoculture and polyculture. Land equivalent ratios (LERs) were calculated from monoculture land equivalents (MLEs) using the method of Ong (1996) as follows:

$\mathrm{LER}_{\text {(polyculture system) }}=\mathrm{MLE}_{\text {(species 1) }}+\mathrm{MLE}_{\text {(species 2) }}$

$\operatorname{MLE}_{(\text {species } X)}=$ yield/unit land area $a_{\text {(polycultureproduction) }}$ $\div$ yield/unit land area ${ }_{\text {(monoculture production) }}$.

Standard horticultural characteristics were used to assess suitability for ornamental landscaping, for which crop yield is a secondary consideration. Growth habit, relative growth rate when planted in close proximity to other woody plants, flower and foliage characteristics, fruit flavor and visual appeal were observed. Potential factors such as ultimate plant height, spread, form, disease resistance, planting longevity were also considered.

\section{Results and Discussion}

Horticultural characteristics of component species. Although berry understory plants differed dramatically in size, shape and general appearance (Fig. 1; Table 1), each berry species demonstrated substantial growth throughout the experiment when grown in monoculture at recommended spacings. Blackberries more than doubled in tissue dry weight from their first to their second fruiting season (i.e., from 2000 to 2001), whereas 2001 dry weights of edible honeysuckle and jostaberry were 1.7 and 1.4 times their 2000 dry weights, respectively. In 2001 , the canopies of blackberry and jostaberry nearly filled the available volume within the plot whereas edible honeysuckle canopies did not fill their allotted space. There was also an observed difference in the growth habits of the two edible honeysuckle cultivars. 'Blue Belle' had an upright habit while 'Blue Velvet' was more recumbent in form (Fig. $1 C$ and D). In addition, 'Blue Belle' leafed out and flowered

Table 2. Mean shoot length/tree and trunk cross-sectional area of apple grown in monoculture and polyculture at two understory crop spacings.

\begin{tabular}{|c|c|c|c|c|c|c|}
\hline \multirow[b]{2}{*}{ Treatment } & \multicolumn{2}{|c|}{1999} & \multicolumn{2}{|c|}{2000} & \multicolumn{2}{|c|}{2001} \\
\hline & $\begin{array}{l}\text { Shoot length/ } \\
\text { tree }(\mathrm{m})\end{array}$ & $\begin{array}{c}\text { Trunk } \\
\text { cross-sectional } \\
\text { area } \\
\left(\mathrm{cm}^{2}\right)\end{array}$ & $\begin{array}{l}\text { Shoot length/ } \\
\text { tree }(\mathrm{m})\end{array}$ & $\begin{array}{c}\text { Trunk } \\
\text { cross-sectional } \\
\text { area } \\
\left(\mathrm{cm}^{2}\right)\end{array}$ & $\begin{array}{l}\text { Shoot length/ } \\
\left(\mathrm{cm}^{2}\right)\end{array}$ & $\begin{array}{c}\text { Trunk } \\
\text { cross-sectional } \\
\text { area } \\
\left(\mathrm{cm}^{2}\right)\end{array}$ \\
\hline$\overline{\text { Apple }}$ & $0.59 \mathrm{ab}^{\mathrm{z}}$ & 2.8 abc & $2.26 \mathrm{a}$ & $10.7 \mathrm{a}$ & $4.35 \mathrm{a}$ & $19.3 \mathrm{a}$ \\
\hline Apple-blackberry $(\mathrm{R})^{\mathrm{y}}$ & $0.63 \mathrm{a}$ & $3.0 \mathrm{ab}$ & $1.85 \mathrm{ab}$ & $9.1 \mathrm{ab}$ & $2.65 \mathrm{bc}$ & $16.3 \mathrm{abc}$ \\
\hline Apple-blackberry $(C)^{x}$ & $0.45 \mathrm{~b}$ & $2.5 \mathrm{bc}$ & $1.38 \mathrm{bc}$ & $7.7 \mathrm{bc}$ & $2.13 \mathrm{~cd}$ & $13.4 \mathrm{~cd}$ \\
\hline Apple-edible honeysuckle (R) & $0.43 \mathrm{~b}$ & $2.3 \mathrm{c}$ & $2.12 \mathrm{a}$ & $9.0 \mathrm{ab}$ & $3.44 \mathrm{ab}$ & $16.5 \mathrm{abc}$ \\
\hline Apple-edible honeysuckle (C) & $0.58 \mathrm{ab}$ & $2.7 \mathrm{abc}$ & $2.16 \mathrm{a}$ & $10.0 \mathrm{a}$ & $3.60 \mathrm{ab}$ & $17.9 \mathrm{ab}$ \\
\hline Apple-jostaberry (R) & $0.59 \mathrm{ab}$ & $3.3 \mathrm{a}$ & $1.73 \mathrm{ab}$ & $9.4 \mathrm{ab}$ & $2.16 \mathrm{~cd}$ & $14.5 \mathrm{bcd}$ \\
\hline Apple-jostaberry (C) & $0.42 \mathrm{~b}$ & $2.3 \mathrm{c}$ & $0.97 \mathrm{c}$ & $6.3 \mathrm{c}$ & $1.53 \mathrm{~d}$ & $11.1 \mathrm{~d}$ \\
\hline
\end{tabular}

${ }^{2}$ Treatment means were separated using Duncan's multiple range test $(P \leq 0.05)$. Means followed by the same letter are not significantly different.

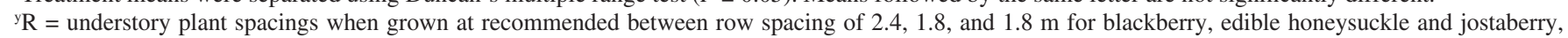
respectively.

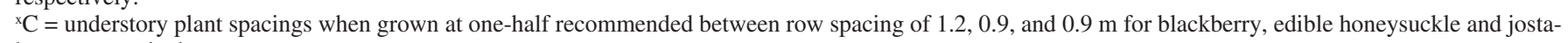
berry, respectively. 
Table 3. Mean number of apple blossom clusters, percent fruit set, yield and apple weight when grown in monoculture and polyculture at two understory crop spacings.

\begin{tabular}{|c|c|c|c|c|c|c|c|c|c|}
\hline \multirow[b]{2}{*}{ Treatment } & \multicolumn{4}{|c|}{2000} & \multicolumn{4}{|c|}{2001} & \multirow{2}{*}{$\begin{array}{c}2002 \\
\text { Flower } \\
\text { clusters }\end{array}$} \\
\hline & $\begin{array}{l}\text { Flower } \\
\text { clusters }\end{array}$ & $\begin{array}{c}\text { Fruit } \\
\text { set }(\%)\end{array}$ & $\begin{array}{c}\text { Yield } \\
\text { (kg/tree) }\end{array}$ & $\begin{array}{l}\text { Fruit wt } \\
\text { (g/fruit) }\end{array}$ & $\begin{array}{l}\text { Flower } \\
\text { clusters }\end{array}$ & $\begin{array}{c}\text { Fruit } \\
\text { set }(\%)\end{array}$ & $\begin{array}{c}\text { Yield } \\
\text { (kg/tree) }\end{array}$ & $\begin{array}{l}\text { Fruit wt } \\
\text { (g/fruit) }\end{array}$ & \\
\hline$\overline{\text { Apple }}$ & 43 & 1.0 & 0.61 & $129 \mathrm{a}^{\mathrm{z}}$ & $403 \mathrm{a}$ & $7.2 \mathrm{a}$ & $24.49 \mathrm{a}$ & $158 \mathrm{a}$ & $365 \mathrm{a}$ \\
\hline Apple-blackberry $(\mathrm{R})^{\mathrm{y}}$ & 24 & 2.5 & 0.62 & $149 \mathrm{a}$ & $139 \mathrm{c}$ & $1.5 \mathrm{~b}$ & $1.31 \mathrm{~d}$ & $68 \mathrm{~b}$ & $116 \mathrm{bcd}$ \\
\hline Apple-blackberry $(C)^{x}$ & 37 & 0.7 & 0.18 & $97 \mathrm{ab}$ & $6 \mathrm{~d}$ & $2.9 \mathrm{~b}$ & $0.10 \mathrm{~d}$ & $\mathrm{ND}^{\mathrm{w}}$ & $89 \mathrm{~cd}$ \\
\hline Apple-edible honeysuckle (R) & 34 & 3.4 & 1.37 & $102 \mathrm{ab}$ & $358 \mathrm{ab}$ & $6.8 \mathrm{a}$ & $17.95 \mathrm{~b}$ & $155 \mathrm{a}$ & $243 \mathrm{ab}$ \\
\hline Apple-edible honeysuckle (C) & 31 & 2.3 & 0.93 & $176 \mathrm{a}$ & $266 \mathrm{~b}$ & $6.5 \mathrm{a}$ & $10.73 \mathrm{c}$ & $148 \mathrm{a}$ & $221 \mathrm{bc}$ \\
\hline Apple-jostaberry (R) & 43 & 3.1 & 1.13 & $159 \mathrm{a}$ & $50 \mathrm{~cd}$ & $1.3 \mathrm{~b}$ & $0.29 \mathrm{~d}$ & ND & $52 \mathrm{~d}$ \\
\hline Apple-jostaberry (C) & 24 & 0.0 & 0.00 & $0 \mathrm{~b}$ & $13 \mathrm{~d}$ & $0.4 \mathrm{~b}$ & $0.13 \mathrm{~d}$ & ND & $23 \mathrm{~d}$ \\
\hline
\end{tabular}

${ }^{2}$ Treatment means were separated using Duncan's multiple range test $(P \leq 0.05)$. Means followed by the same letter are not significantly different.

${ }^{\mathrm{y}} \mathrm{R}=$ understory plant spacings when grown at recommended between row spacing of $2.4,1.8$, and $1.8 \mathrm{~m}$ for blackberry, edible honeysuckle and jostaberry, respectively.

${ }^{\mathrm{x}} \mathrm{C}=$ understory plant spacings when grown at one-half recommended between row spacing of $1.2,0.9$, and $0.9 \mathrm{~m}$ for blackberry, edible honeysuckle and jostaberry, respectively.

${ }^{\mathrm{w}} \mathrm{ND}=$ values were not determined; apple fruit weight could not calculated due to a lack of harvested apples.

earlier in the spring and lost its leaves earlier in the fall than did 'Blue Velvet'. Significant variability in growth habit, leaf pubescence and fruit characteristics among $L$. caerulea populations has been reported previously (Kukluna, 1985).

By the second fruiting season, 'Navaho' blackberry yields averaged $>3.1 \mathrm{~kg} /$ plant, demonstrating productivity similar to plants of the same age grown at Bald Knob or Clarksville, Ark., as reported by Moore and Clark(1989a). A

Fig. 2. Second fruiting season (2001) plant dry weight of 'Navaho' blackberry (BB), 'Josta' jostaberry (JB), and 'Blue Belle' and 'Blue Velvet' edible honeysuckle (HS) grown in monoculture and polyculture with apple at two understory crop spacings. Black, crosshatched, gray, and white bars represent berry $(\mathrm{R})$, berry $(\mathrm{C})$, apple-berry (R) and apple-berry (C) treatments, respectively. Dry wts were estimated by regressions based on the following measurements: 'Navaho' blackberry $=$ the number of canes, the number of laterals, and the length of the first and third longest shoots $\left(r^{2}=0.72\right)+$ the cumulative dry weight of previously-pruned canes; 'Blue Belle' edible honeysuckle $=$ the diameter of the largest scaffold measured at $4 \mathrm{~cm}$ above the soil surface, the number of scaffolds, the length of the first and third longest shoots, and the width and height of the plant $\left(r^{2}=0.89\right)$; 'Blue Velvet' edible honeysuckle $=$ the number of scaffolds, the number of laterals and the length of the longest $\operatorname{shoot}\left(r^{2}=0.91\right)$; 'Josta' jostaberry $=$ the number of scaffolds, the diameter of the largest scaffold measured at $5 \mathrm{~cm}$ above the soil surface, the length of the first and second longest shoots, the number of laterals, and the width and height of the plant $\left(r^{2}=0.55\right)$.

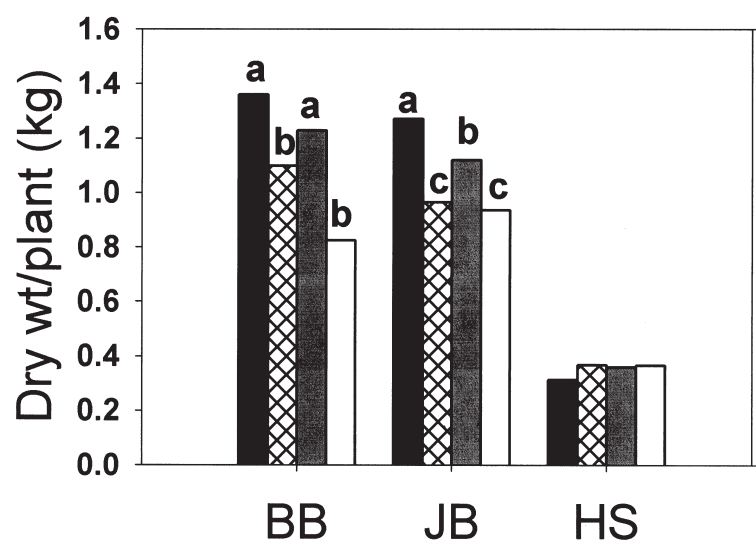

high percentage of 'Navaho' blackberry flowers set fruit in both fruiting seasons studied. Fruit weights, although lighter than many commercial blackberry species (Galletta et al., 1998; Moore and Clark, 1989b), were typical for this cultivar (Moore and Clark, 1989a; Perkins-Veazie etal., 1996). 'Navaho' blackberry fruit weights apparently declined in relation to crop load.

Edible honeysuckle bloom was phenologicaly separated between cultivars, with 'Blue Belle' flowering 2 weeks earlier than 'Blue Velvet' in 2000 and 1 week earlier in 2001. Cross-pollination is nearly essential for fruit set among edible Lonicera. According to Plekhanova (1982), fruit set among 45 varieties was $<9 \%$ when naturally or artificially self-pollinated, but was $30 \%$ to $50 \%$ following openpollination. Harvestable amounts of fruit were not produced in 2000, but there was enough of an overlap in bloom times for cross-pollination to occur and a partial fruit crop to be produced in 2001 (Table 1). Nevertheless, the 2001 yield of edible honeysuckle was minimal and its fruit weight was low. Even if fruit set had been $100 \%$, the average yield/plant would not have exceeded $100 \mathrm{~g}$. Despite equivalent yields in 2001, the two cultivars significantly differed in number of flowers produced, percent fruit set and fruit weight (Table 1). 'Blue Velvet' produced more than twice as many flowers per plant than did 'Blue Belle', and its fruit weighed nearly double that of 'Blue Belle'. However, percent fruit set was four times higher in 'Blue Belle' than in 'Blue Velvet.' Whether poor fruit set and increased fruit weight in 'Blue Velvet' resulted from the lack of cross-pollination and subsequent yield compensation, respectively, is unknown. Clearly, 'Blue Belle' and 'Blue Velvet' are unsuited for one another as pollen sources when grown in the environment of northeastern Ohio. The taxonomy of this polymorphic species is complex due toits extremely wide geographic and ecological distribution. Therefore, it is possible that the two cul- tivars used in this study are from different subspecies of Lonicera caerulea. In Russian literature, plants with forms like that of 'Blue Belle' have been classified at $L$. caerulea subsp. edulis, while those that resemble 'Blue Velvet' have been called L. emphyllocalyx, L. caerulea subsp. emphyllocalyx or L. caerulea subsp. kamtschatica (Maxine Thompson, personal communication).

The 2000 fruit weights of 'Josta', a black currant $\times$ gooseberry hybrid, were nearly equal to those reported for this cultivar and the jostaberry breeding selection, ORUS 10, by Pluta and Hummer (1995). In contrast, about 15 times as many fruit per plant were harvested in 2001, but their average weight was reduced by $28 \%$. Although jostaberry fruit has been described as resembling those of small gooseberry cultivars (Bauer, 1986, Måge, 2002), the yield of jostaberries in either year was substantially lower than those estimated for mature gooseberries or currants (Barney, 1999; Harmatet al., 1990). Small fruit size, poor fruit set and perhaps, juvenility (especially in 2000), contributed to this low yield. Fruit size and fruit set and yield potential for black currants, jostaberries and some gooseberries benefit moderately to substantially from cross-pollination (Harmat et al., 1990; Strik

Fig 3. Second fruiting season (2001) yield/plant of 'Navaho' blackberry (BB), 'Josta' jostaberry (JB), and 'Blue Belle' and 'Blue Velvet' edible honeysuckle (HS) grown in monoculture and polyculture with apple at two understory crop spacings. . Black, crosshatched, gray, and white bars represent berry $(\mathrm{R})$, berry $(\mathrm{C})$, apple-berry (R) and apple-berry (C) treatments, respectively. The left $\mathrm{Y}$ axis represents yield values for $\mathrm{BB}$ and $\mathrm{JB}$ whereas the right $\mathrm{Y}$ axis represents yield values for $\mathrm{HS}$.

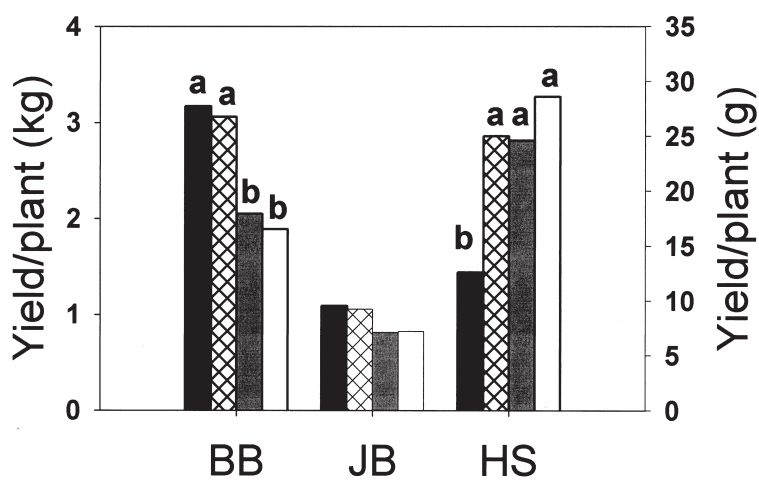


Table 4. Estimated 2001 Land Equivalent Ratios (LER) for several types of apple polyculture systems.

\begin{tabular}{lccc}
\hline Treatment & $\begin{array}{c}\text { Monoculture land } \\
\text { equivalent } \\
\text { for apple }^{z}\end{array}$ & $\begin{array}{c}\text { Monoculture land } \\
\text { equivalent } \\
\text { for berry }\end{array}$ & LER $^{\mathrm{y}}$ \\
\hline Apple $^{\mathrm{z}}$-blackberry (R) & 0.053 & 0.659 & 0.71 \\
Apple-blackberry (C) $^{\mathrm{w}}$ & 0.004 & 0.617 & 0.62 \\
Apple-edible honeysuckle (R) & 0.733 & 2.083 & 2.82 \\
Apple-edible honeysuckle (C) & 0.438 & 1.160 & 1.60 \\
Apple-jostaberry (R) & 0.012 & 0.744 & 0.75 \\
Apple-jostaberry (C) & 0.005 & 0.781 & 0.79 \\
\hline
\end{tabular}

${ }^{\mathrm{z}}$ Apple monoculture land equivalent $=$ apple polyculture yield/unit land area $\div$ apple monoculture yield/unit land area (Table 3).

${ }^{\mathrm{y}}$ Berry monoculture land equivalent = berry polyculture yield/unit land area $(\mathrm{R}$ or $\mathrm{C}) \div$ berry monoculture yield/unit land area (R or C), respectively, (Table 1, Fig. 3).

${ }^{x}$ LER = apple monoculture land equivalent + berry monoculture land equivalent. On a per hectare basis LER is the number of hectares needed for monoculture (i.e., separate) production of the apple and berry crops in order to obtain equivalent weights of fruit as those produced on a hectare of apple-berry polyculture. LER values $<1$ suggest monoculture as the most efficient cropping system whereas values $>1$ identify polyculture as the most efficient cropping system.

${ }^{\mathrm{w}} \mathrm{R}=$ understory plant spacings when grown at recommended between row spacing of $2.4,1.8$, and $1.8 \mathrm{~m}$ for blackberry, edible honeysuckle and jostaberry, respectively.

${ }^{\mathrm{v}} \mathrm{C}=$ understory plant spacings when grown at one-half recommended between row spacing of $1.2,0.9$, and $0.9 \mathrm{~m}$ for blackberry, edible honeysuckle and jostaberry, respectively.

and Bratsch, 1993), and gooseberry fruit size is linearly related to seed no./fruit (Måge 2002). Unfortunately, at the time of planting, 'Josta' was the only commercially available cultivar of jostaberry, so potential benefits from cross pollination were not examined herein.

'GoldRush' apple has been described as being moderately vigorous, highly precocious cultivar with superior disease resistance and fruit quality characteristics (Janick, 2001). Herein, 'GoldRush' apples in monoculture (i.e., controls) nearly quadrupled in both shoot length and trunk cross-sectional area in their second year of growth and nearly doubled in size again in the following year (Table 2). As is typical of this cultivar, 'GoldRush' trees set and matured a limited number of fruit in their second season (Table 3). By the third growing season, yield parameters increased dramatically. Contrastingly, as part of a multi-regional rootstock trial, plantings of 'Starkspur Supreme Delicious'/M.7 did not surpass the 2001 'GoldRush'/M.7 yield until their sixth season of growth (NC-140, 1991). The fruit weight (158 g/fruit) of 'GoldRush' was typical of this moderately-sized apple.

Berry growth and yield parameters as affected by cultural systems. Growth and yield parameters were influenced by understory plant spacing and, in some cases, by the presence of an apple overstory (Figs. 2 and 3). In 2000, the estimated dry weight of blackberries grown in control plots differed significantly only from those grown in polyculture with apple at close spacing (data not shown). By the end of 2001, the blackberries in both close-spaced treatments were significantly smaller than those grown at recommended spacing, but there was no difference between treatments with respect to the presence or absence of an apple tree (Fig. 2). Conversely, plant spacing did not affect blackberry yields, but yields were significantly decreased when blackberries were grown in polyculture (Fig. 3). Treatments did not affect edible honeysuckle growth, but when considered singly, 'Blue Velvet' growth was significantly enhanced (i.e., $27 \%$ to $35 \%$ greater) when cultured at close spacings or when associated with an apple overstory (data not shown). This trend was observed in the yield of both edible honeysuckle cultivars. In 2001, jostaberry dry weight was significantly reduced by both plant spacing and polyculture. The addition of an apple tree inhibited jostaberry growth but not to as large a degree as decreasing the spacing between rows of jostaberry plants. Jostaberry yields were not significantly reduced when grown in polyculture with apple.

Apple growth and yield parameters as affected by cultural systems. Apple growth was not affected by understory plantings during the establishment year(Table 2). However, by 2000, the apple-blackberry (C) and apple-jostaberry (C) treatments significantly reduced apple shoot length/tree and trunk cross-sectional area compared to that of the control. The detrimental effect of these polyculture treatments on apple growth was even more pronounced in 2001, with mean cumulative shoot length and mean trunk cross-sectional areas being reduced by as much as $65 \%$ and $42 \%$, respectively, over those exhibited by the control. Similarly, in 2001, apple shoot growth in control plots was significantly greater than it was in apple-blackberry (R) or apple-jostaberry (R) treatments, and trunk cross sectional area was significantly greater in controls than in apple-jostaberry (R) plots. Although blackberry and jostaberry understory plantings reduced apple growth, first at close spacing and eventually at recommended spacing, an understory of edible honeysuckle at either spacing had no apparent effect upon the growth of apple trees.

Apple yield parameters followed similar trends with respect to treatment as did growth parameters. Treatment had no significant effect on mean apple yield in the first fruiting season, but by 2001 , it was significantly reduced in apple-berry polycultures with respect to the control, regardless of understory plant spacing (Table 3). In this season, an understory of blackberry or jostaberry plants reduced yield to a significantly greater extent than did an edible honeysuckle understory. Yield was so reduced in these treatments that fruit weight could not be calculated for either apple-jostaberry treatment or for the apple-blackberry $(\mathrm{C})$ treatment, since a sufficient sample of apples was not available. The number of flower clusters, percent fruit set and fruit weight were highly correlated with yield $(r=0.86,0.76$, and 0.79 , respectively, $P<0.0001)$ on an individual tree basis. Thus, among apple-blackberry treatments, apple-jostaberry treatments and controls, statistical differences in yield determinants followed a pattern similar to those displayed by yield. Apple means in apple-edible honeysuckle plots differed significantly from those of the control only for the number of flower clusters present in close-spaced plantings. In 2002, the flower cluster means were nearly identical to those of the previous season; the edible honeysuckle (R) treatment did not significantly differ from the control, but all other treatments did.

Of the berry species herein, only blackberry has been previously examined as a potential understory planting for young apple trees (Shribbs and Skroch, 1986). By the fourth year of their study, wild, trailing blackberries planted within the tree row under 'Smoothee Golden Delicious' on seedling rootstock resulted in some significant reductions in tree growth parameters. However, the influence of a blackberry understory on tree trunk diameter, on the relative growth rate of the trunk diameter, stem diameter or shoot length and on yield was minimal in comparison with the effect of other ground covers within their study. The invasive behavior of trailing blackberry were considered to be a weedy characteristic of more concern than its ability to compete with the tree for resources. In contrast, the thornless, erect 'Navaho' blackberry of our study was highly competitive. Moreover, prolific suckering under the landscape fabric suggested that it could also become highly invasive.

Suitability of polycultures and polyculture constituents for fruit production or edible landscaping. As a measure of plant performance for fruit production, land equivalent ratios (LER) were calculated to evaluate the efficiency of each polyculture system (Table 4). The monoculture land equivalents (MLEs) were less than one for apple, blackberry and jostaberry in all apple-blackberry and apple-jostaberry polyculture treatments, indicating that production in polyculture plots reduced the yield of each crop relative to what would have been produced in a similar-sized monoculture plot. As discussed in detail by Rivera (2002), reduced apple and berry yields in these treatments likely resulted from intra- and/or interspecific competition for light, and/or nutrient resources. The competitive superiority of the understory berry over that of the apple was especially noticeable in the apple-blackberry (C) and both apple-jostaberry treatments where apple yields were $<5$ fruit/ plant. Also, competition among plants was apparently exacerbated by the culture of understory berries at close spacing. LER values for these treatments ranging from 0.62 to 0.79 indicated that a producer would need $21 \%$ to $38 \%$ less land planted in two separate monocultures to acquire tonnages of apple and blackberry or apple and jostaberry fruit equivalent to those which could be produced in polyculture. However, LER values favored polyculture for apple-ediblehoneysuckle treatments, primarily 
because edible honeysuckle yields, regardless of plant spacing, were higher in polycultures than in their respective monoculture. LER values notwithstanding, there may be serious impediments to successful commercial production of apple-edible honeysuckle polycultures. First, the germplasm within $L$. caerulea should be thoroughly examined in order to identify genotypes with complementary floral phenology that demonstrate higher yield potential than those in this study. Moreover, genotypes should be tested more thoroughly for their adaptation response to prolonged polyculture production. In a companion study, 'Blue Velvet' plants performed equally as well whether planted under nursery whips or 4-year-old trees of 'GoldRush' apple, but the growth and yield of 'Blue Belle' was reduced grown under the older trees (Rivera, 2002). Finally, as it is virtually an unknown commodity, the commercial viability of any edible honeysuckle production scheme would benefit from extensive pre- and postharvest cultural research, and require the establishment of an infrastructure to handle the fruit and the development of a market.

The appeal of apple-berry polycultures in the establishment of a landscape has never been greater, as residential landscapes are expanding beyond simple aesthetic appeal into a more ecological or sustainable purpose (Beck et al., 2002; Beck and Quigley 2002). Each of the polyculture constituents exhibited unique, beneficial attributes with respect to their use as components within an edible landscape. As a landscape overstory, 'GoldRush' apple had merit because it was moderately vigorous, but highly precocious, producing a noteable crop three years after planting. Its superior resistance to apple scab [Venturia inaequalis (Cke.) Wint.] should reduce the necessity for the periodic application of fungicides. The apple is mediumsized and often lacks a clear finish, but its eating quality is excellent, exhibiting an intense apple flavor even after storage or processing (Janick, 2001). As there are relatively few fruiting shrubs, aside from ericaceous species, that will flourish in partial shade, the apple-edible honeysuckle combination seems particularly practicable during the years of tree establishment. In this study, edible honeysuckle performed well in close proximity to apple, without being overly competitive or invasive and produced a compact, relatively dense canopy with attractive foliage and diminutive, but attractive and fragrant flowers. As a native of eastern Siberia and the Kurile Islands, it is reported to be cold hardy, although Ohio's relatively mild winters of 1999 through 2002 failed to test this putative trait. Diversity within the species is ample (Kuklina, 1985), providing opportunities for selecting pheno- logically similar individuals that will perform well within any given landscape environment. 'Navaho' blackberry's vigor and competitive advantage made it less successful than edible honeysuckle as an understory plant. However, its thornless, erect habit, its relative disease resistance and its superior fruit quality (Moore and Clark, 1989a; Perkins-Veazie et al., 1996) are desirable traits supporting its inclusion in more open areas of the home garden. Similarly, jostaberry may be more appropriate as an element in a formal hedge or background planting than as an understory plant. As such, they are relatively easy to care for, but with more effort, they may also be espaliered or trained to a trellis system (Barney, 1999; Harmatetal., 1990; Strik and Bratsch, 1993). 'Josta' is thornfree, resistant to gray mold (Botrytis cinerea L.), powdery mildew [Sphaerotheca mors-uvae Schw. (Berk. et Curt.)] and white pine blister rust (Cronartium ribicola J.C. Fischer) and is recommended for home gardens (Pluta and Hummer, 1995). As these woody materials are deciduous, spring ephemerals could be added as another understory layer for early season interest.

\section{Literature Cited}

Altieri, M.A. 1987. Agroecology: The scientific basis of alternative agriculture. Westview Press, Boulder, Colo.

Barney, D.L. 1999. How to grow currants and gooseberries. Univ. of Idaho Sandpoint Res. Ext. Ctr. July 2003. <http://www.webpages.uidaho. edu/ sandpnt/ribes.htm>.

Bauer, A. 1986. New results of breeding Ribes nidigrolaria: Amphidiploid species hybrids between black currant and gooseberry. Acta Hort. 183:107-110.

Beck, T.B., J. Heimlich, and M.F. Quigley. 2002. Gardeners' perceptions of the aesthetics, manageability, and sustainability of residential landscapes. Appl. Environ. Educ. Commun. 1:163-172.

Beck, T.B. and M.F. Quigley. 2002. Edible landscaping. Ohio State Univ. Ext. Fact Sheet HYG-1255-02. Aug. 2003.<http://ohioline.osu. edu/hyg-fact/1000/125.html>.

Corlett, J.D., C.K. Ong, C.R. Black, and J.L. Monteith. 1992a. Above and below ground interactions in a Leucaena/millet alley cropping system. I. Experimental design, instrumentation and diurnal trends. Agr. For. Meteorol. 60:53-72.

Corlett, J.D., C.R. Black, C.K. Ong, and J.L. Monteith. 1992b. Above and below ground interactions in a Leucaena/millet alley cropping system. II. Light interception and dry matter production. Agr. For. Meteorol. 60:73-91.

Creasy, R. 1982. The complete book of edible landscaping. Sierra Club Books, San Francisco.

Farrell,J.G. 1987. Agroforestry systems, p. 149-158. In: M.A. Altieri (ed.). Agroecology: The scientific basis of alternative agriculture. Westview Press, Boulder, Colo.
Funt, R.C, M.A. Ellis, R. Williams, D. Doohan, J.C. Scheerens, and C. Welty. 2001. Brambles-Production management and marketing. Ohio State Univ. Ext. Bul. 782

Galletta, G.J., A.D. Draper, J.L. Maas, R.M. Skirvin, A.G. Otterbacher, H.J. Swartz, and C.K. Chandler. 1998. 'Chester Thornless' blackberry. Fruit Var. J. 52(3):118-122.

Harmat, L., A. Porpaczy, D.C. Himelrick, and G.J. Galletta. 1990. Currant and gooseberry management, p. 245-272. In: G.J. Galletta and D.C Himelrick (eds.). Small fruit crop management. Prentice Hall, Englewood Cliffs, N.J.

Hagy, F. 1990. Landscaping with fruits and vegetables. The Overlook Press, New York.

Janick, J. 2001. 'GoldRush' apple. J. Amer. Pomol. Soc. 55(4):194-196.

Kukluna, A.G. 1985. Variation among populations of Blue Lonicera in Siberia. Bul. Glavnogo Botanicheskogo Sada 136:52-55.

Leuty, T. 1999. Intercropping trees and annual crops. Ontario Ministry of Agriculture and Food. July 2003. <http://www.gov.on.ca:80/OMAFRA/ english/crops/facts/info_intercrop.htm>.

Måge, F. 2002. A comparison of seven gooseberry cultivars with respect to yield components and fruit quality. Acta Hort. 585(2):481-487.

Moore, J.N. and J.R. Clark. 1989a. 'Navaho' erect thornless blackberry. HortScience 24(5):863-865.

Moore, J.N. and J.R. Clark. 1989b. 'Chocktaw' blackberry. HortScience 24(5):862-863.

NC-140. 1991. Performance of 'Starkspur Supreme Delicious' apple on 9 rootstocks over 10 years in the NC-140 cooperative planting. Fruit Var. J. 45(4):192-199.

Ong, C.K. 1996. A framework for quantifying the various effects of tree-crop interactions, p. 1-24. In: C.K. Ong and P. Huxley (eds.). Tree-crop interactions: A physiological approach. $\mathrm{CAB}$ Intl., Wallingford, U.K.

Perkins-Veazie, P., J.K. Collins, and J.R. Clark. 1996. Cultivar and maturity affect postharvest quality of fruit from erect blackberries. HortScience 31(2):258-261.

Plekhanova, M.N. 1982. Study of self-and crosspollination in honeysuckle using luminescent microscopy (Lonicera). Biulleten Vsesousnogo Instituta Rastenievodstva 126:53-58.

Pluta, S. and K.E. Hummer. 1995. Highly rated gooseberries and currants at the USDA-ARS National Clonal Germplasm Repository, Corvallis, Oregon. July 2003. <http://www.ars-grin. gov/ars/PacWest/Corvallis/ncgr/cool/top.ribes. $\mathrm{html}>$.

Rivera, T.M. 2002. Competitive performance in an apple-berry polyculture. $\mathrm{PhD}$ diss. The Ohio State Univ., Columbus.

SAS Institute. 1990. SAS/STAT user's guide. $4^{\text {th }}$ ed. version 6. SAS Inst., Inc., Cary, N.C.

Shribbs, J.M. and W.A. Skroch. 1986. Influence of 12 ground cover systems on young 'Smoothee Golden Delicious' apple trees: I. growth. J. Amer. Soc. Hort. Sci. 11(4):525-528.

Strik, B.C. and A.D. Bratsch. 1993. Growing currants and gooseberries in your home garden. Ore. State Univ. Ext. Bul. EC 1361. 